\title{
EXTREME HYPOCHLOREMIA IN DOGS INDUCED \\ BY NITRATE ADMINISTRATION
}

By

EDWIN PEELLE HIATT

Thesis submitted to the Faculty of the Graduate School

of the University of Maryland in partial

fulfillment of the requirements for

the degree of Doctor of Philosophy.

1940 
UMI Number: DP70029

All rights reserved

INFORMATION TO ALL USERS

The quality of this reproduction is dependent upon the quality of the copy submitted.

In the unlikely event that the author did not send a complete manuscript and there are missing pages, these will be noted. Also, if material had to be removed, a note will indicate the deletion.

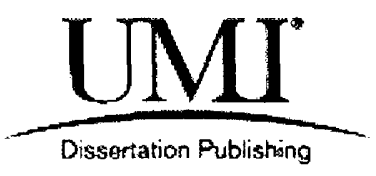

UMI DP70029

Published by ProQuest LLC (2015). Copyright in the Dissertation held by the Author.

Microform Edition (C) ProQuest LLC.

All rights reserved. This work is protected against

unauthorized copying under Title 17, United States Code

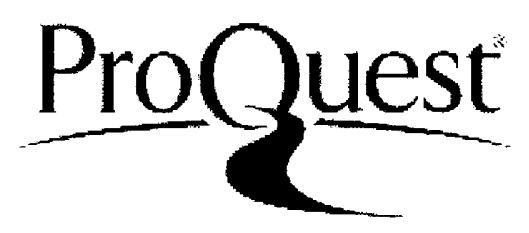

ProQuest LLC.

789 East Eisenhower Parkway

P.O. Box 1346

Ann Arbor, Ml 48106 - 1346 


\section{MABLE OF CONTENTS}

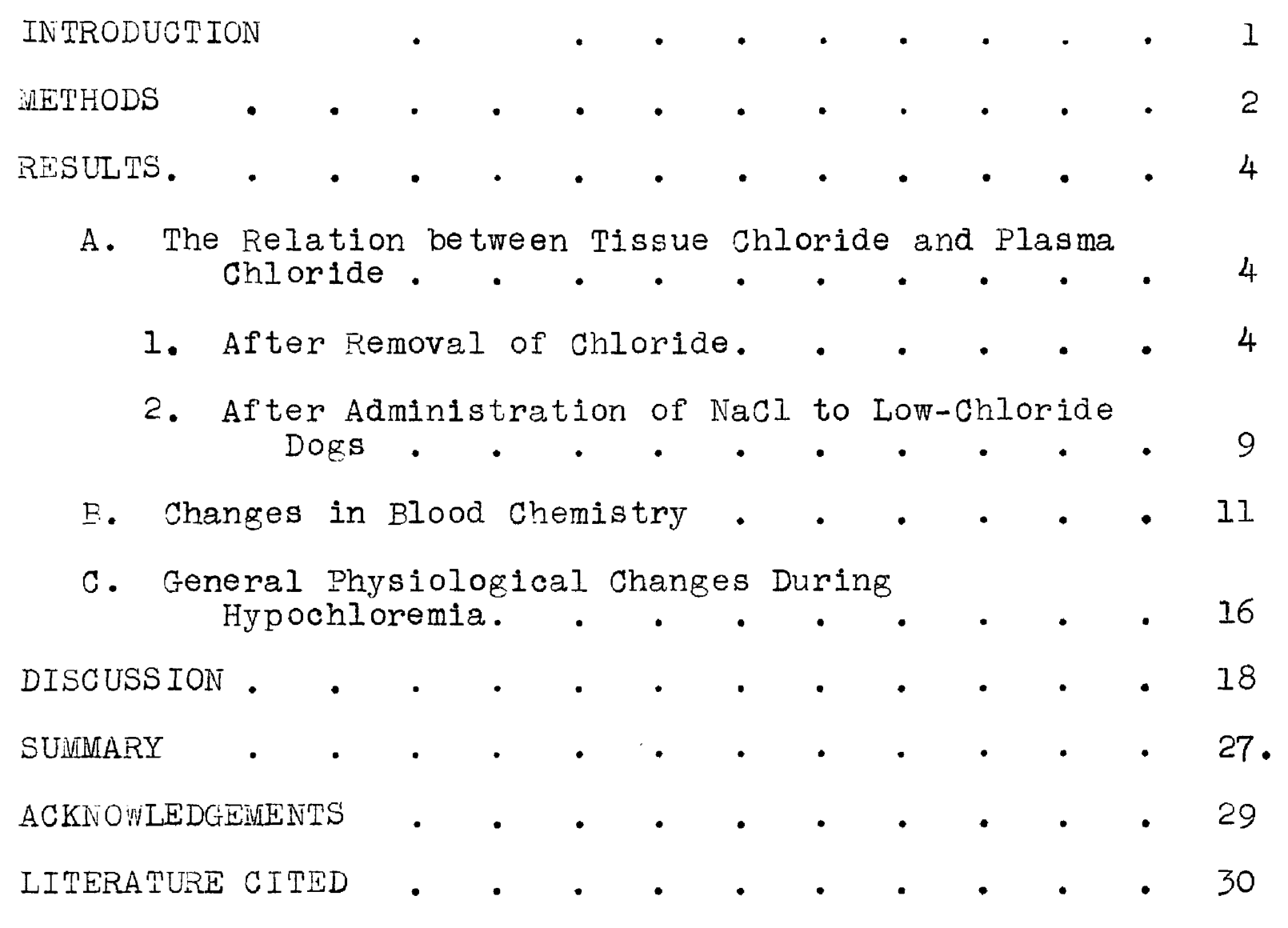




\section{LIST OF TAELES}

TABLE I: Tissue Chlorides in Normal and Low-Chloride

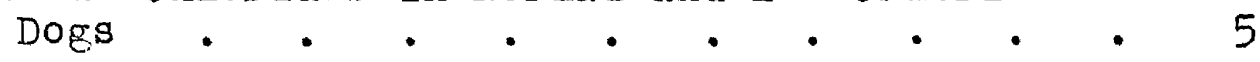

TABLE II: Tissue Chlorides of Low-Chloride Dogs

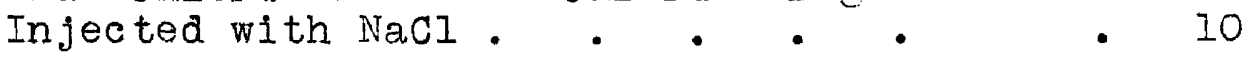

TABLE III: Rate of Excretion of Nitrate. . . . . 12

TAELE IV: Retention of Nitrate in Low-Chloride Animals. 13

TABLE V: Penetration of Nitrate into cerebrospinal Fluid • • • • • • • • • • 13

TABLE VI: Blood Chemistry of Normal and Low-Chloride Dogs . . . . . . • • • . 14 


\section{LIST OF FIGURES}

FIGURE 1: Average tissue chloride concentration plotted against plasma chloride concentration at various low-chloride levels. Expressed as percentage of average normal value . . 7

FIGURE 2: Individual tissue chloride concentrations plotted against plasma chloride concentration at various low-chloride levels. Expressed as percentage of average normal value • $\quad . \quad \cdot \quad \cdot \quad \cdot \quad \cdot \quad 8$

FIGURE 3: Typical changes in blood constituents of low-chloride dogs. 


\section{INTRODUCTION}

The chloride ion is, next to sodium, the most common ion, and by far the most common anion, in the extracellular body fluids of animals. In vertebrates the concentration of chloride in these fluids is normally regulated within narrow limits. Normal values for the plasma of dog blood fall between 102 and 115 milliequivalents per liter. Only by dint of drastic treatment can the concentration of chloride be caused to vary much beyond these limits. Langlois and Richet (1900) and Austin and Jonas (1918) have shown that if excess of chloride is administered it is promptly excreted. They have also demonstrated that if chloride is denied the animal the kidneys excrete urine with a very low chloride content, so that the plasma concentration, after dropping ten milliequivalents or so, remains practically constant. Chloride may be lost from the animal body through the urine, the sweat (Moss, 1923 and McCance, 1937), or the alimentary juices (Peters and Van Slyke, 1931; Dragstedt and Ellis, 1930; Ambard and Stahl, 1935; and Bottin, 1936). It may be removed from the animal by plasmapheresis with chloride-free blood (Amberson, Nash et al, 1938) or by intraperitoneal lavage (Darrow and Yannet, 1935). Since our purpose was to maintain chronically low-chlorije dogs in a condition otherwise as near to normal as possible, we chose to force the chloride out by way of the kidneys. Many diuretic agents have been found to cause the production of a high-chloride urine (Fulton et al, 1934 and Grthwald, 
1909). After trying a number of salts (sulfates, bicarbonates, thiocyanates) and various organic compounds containing mercury, we chose $\mathrm{NaNO}_{3}$ as our active agent because we found that (I) it is comparatively non-toxic, (2) it diffuses quickly through animal membranes, and (3) it can cause continued loss of chloride even when the plasma chloride concentration has been reduced far below the usual threshold level for excretion. Keith, Whelan and Bannick (1930) have described the efficacy of ammonium and potassium nitrate as diuretic agents, but we chose sodium for the cation as being more physiological. Langlois and Richet reported in 1900 that large doses of $\mathrm{NaNO}_{3}$ reduced the amount of chloride in the fluids and tissues of dogs by as much as $25 \%$. They accomplished this with what they term a toxic dose of 4 grams per kilogram. ithe used much smaller doses but repeated them frequently in order to reduce the total body chloride and study (1) the equilibrium between plasma chloride and the chloride of various tissues and (2) the changes in the chemistry of the blood.

\section{METHODS}

The most satisfactory method we found for administering large doses of nitrate to our animals was intravenous injection of an hypertonic solution. Tie used a four times isotonic solution, injecting about $20 \mathrm{cc}$. per kilogram at a time. When given by mouth in such quantities the nitrate caused obvious methemoglobinemia, presumably being converted to nitrite by intestinal bacteria (see Keith, Whelan and Bannick, 1930 and Tarr, 1933). With the intravenous injections methemoglobin was 
not formed in quantities sufficient to be detected in the color of the blood.

The dogs were fed on ground meat which had been washed a number of times with tap water and pressed fairly dry. Such treatment reduced the chloride content of the food to a fraction of a milliequivalent per kilogram. This ground meat, cooked with a little dextrose, served to maintain our animals in good condition during the course of an experiment. We have kept dogs on this diet in a low-chloride condition for as long as three months without obvious ill effects.

Plasma and tissue chlorides were analyzed by the Van Slyke open Carius method as applied by Eisenman (1929). Tissue samples were removed after the dog had been killed by pneumothorax under nembutal anesthesia. The samples were passed quickly through a stream of cold water to remove superficial blood and immediately dried with a towel. Approximately one gram samples were taken for analysis.

Plasma bicarbonates were analyzed by the manometric method of Van Slyke and sendroy (1928).

Nitrates were determined with fair accuracy by a modification of the method devised by Chamot, Pratt and Redfield (1911) for water analysis. One cubic centimeter of plasma was treated with tungstate and $\mathrm{H}_{2} \mathrm{SO}_{4}$ to precipitate proteins, and diluted to $10 \mathrm{cc}$. Five cubic centimeters of the supernatant fluid were neutralized, evaporated to dryness, and treated with phenolsulfonic acid reagent. The resulting yellow color was compared colorimetrically with a standard solution. The normal 
amount of nitrate in the blood is very small (Keith, whelan and Bannick, 1930). In our experiments it was taken to be zero, since $0.5 \mathrm{cc}$. of normal plasma does not give a perceptible color with the reagents.

pH readings were made with a NacInnis glass electrode and the electron-ray $\mathrm{pH}$ meter developed by S. B. Young, formerly of the Rockefeller Institute. These determinations were made on venous blood taken under oil and introduced into the electrode without exposure to air. Oxalate adjusted to $\mathrm{pH} 7.4$ was used to prevent coagulation.

Freezing points were determined with a Beckmann thermometer on defibrinated whole blood oxygenated by shaking in air. Lactic acid determinations were made by the method of Friedman, cotonio and Shaffer, as modified by West (1931).

Urea determinations were made on plasma by the method of Van Slyke and Plazin (Peters and Van Slyke, 1932).

\section{RESULTS}

A. The Relation between Tissue Chloride and Plasma chloride

\section{After Removal of Chloride. A series of dogs were} treated with nitrate, causing them to lose chloride in their urine. At various levels of plasma chloride between an average normal value of 108.0 milliequivalents per liter and our lowest value of 32.6 milliequivalents these animals were killed and duplicate tissue samples taken for analysis. The tissues selected were cerebrum, bone (frontal), skin, striated muscle (flexors of thigh), lung, ventricle, liver, spleen, pancreas, adrenal gland, kidney, tendon, stomach ( $f$ undic) and duodenum. 
In addition to these tissues the aqueous humor and cerebrospinal fluid were analyzed. These values were expressed as percentages of the average values for four control dogs. These normal values appear in Table I, beside the values from our lowest dog.

TABLE I

TISSUE CHLORIDES IN NORMAL AND LOW-CHLORIDE DOGS

\begin{tabular}{|c|c|c|c|}
\hline TISSUE & $\begin{array}{c}\text { NORIIAL DOG } \\
\text { m.eq./L. }\end{array}$ & $\begin{array}{c}\text { LOW-CHLORIDE DOG } \\
\text { m.eq./L. }\end{array}$ & $\%$ OF NORMAL \\
\hline Plasma & 108.1 & 32.7 & 30.3 \\
\hline Cerebrum & 31.5 & 8.7 & 27.6 \\
\hline Bone & 22.8 & 6.1 & 26.8 \\
\hline inuscle & 10.9 & 3.6 & 30.2 \\
\hline Lung & 57.4 & 20.5 & 35.8 \\
\hline Ventricle & 24.8 & 8.0 & 33.3 \\
\hline Liver & 31.7 & 9.6 & 30.3 \\
\hline Spleen & 41.6 & 13.8 & 33.2 \\
\hline Pancreas & 33.8 & 10.6 & 31.4 \\
\hline Adrenal gland & 26.3 & 7.1 & 27.0 \\
\hline Kidney & 52.8 & 20.2 & 32.9 \\
\hline Tendon & 63.3 & 21.7 & 34.2 \\
\hline Stomach & 55.1 & 19.8 & 36.0 \\
\hline Duodenum & 40.8 & 12.8 & 31.4 \\
\hline Skin & 52.7 & 25.1 & $47 \cdot 7$ \\
\hline Aqueous humor & 112.5 & 35.6 & 31.6 \\
\hline $\begin{array}{l}\text { Cerebrospinal } \\
\text { fluid }\end{array}$ & 126.9 & 56.1 & 44.2 \\
\hline
\end{tabular}


It can be seen from Table I that the tissues, excepting the skin, have lost about the same percentage of their chloride as has the plasma. In other experiments the skin has not always shown this retention. Its chloride content was extremely variable, probably because of the variable quantity of fat associated with it (see Manery, Danielson and Hastings, 1938 ). Padtberg (1910) and Skelton (1927) have regarded the skin as a storehouse for salt and water. If this is true such variability would be expected. The chloride of the aqueous humor decreased with the plasma chloride, but the cerebrospinal fluid shows a retention of chloride. This has been a consistent finding. The cerebrospinal fluid was apparently insulated from the influence of changes in the plasma.

Fig. I shows the averages of all the tissues of eight dogs at various plasma chloride levels, expressed as percentages of normal. It can be seen that the tissue chloride content varies in direct proportion to plasma chloride concentration. In Fig. 2 five tissues are shown individually. We have selected (I) kidney, representing a glandular tissue, (2) cerebrum, representing a nervous tissue, (3) lung, representing a connective tissue, (4) ventricle, representing a muscular tissue, and (5) stomach, representing a mixed tissue. Tissues from eleven dogs are shown. In none of these tissues did the chloride deviate consistently to either side of direct proportionality to the plasma chloride. Although the individual tissues. showed more variation than did the averages shown in Fig. I, the relationship is the same. 


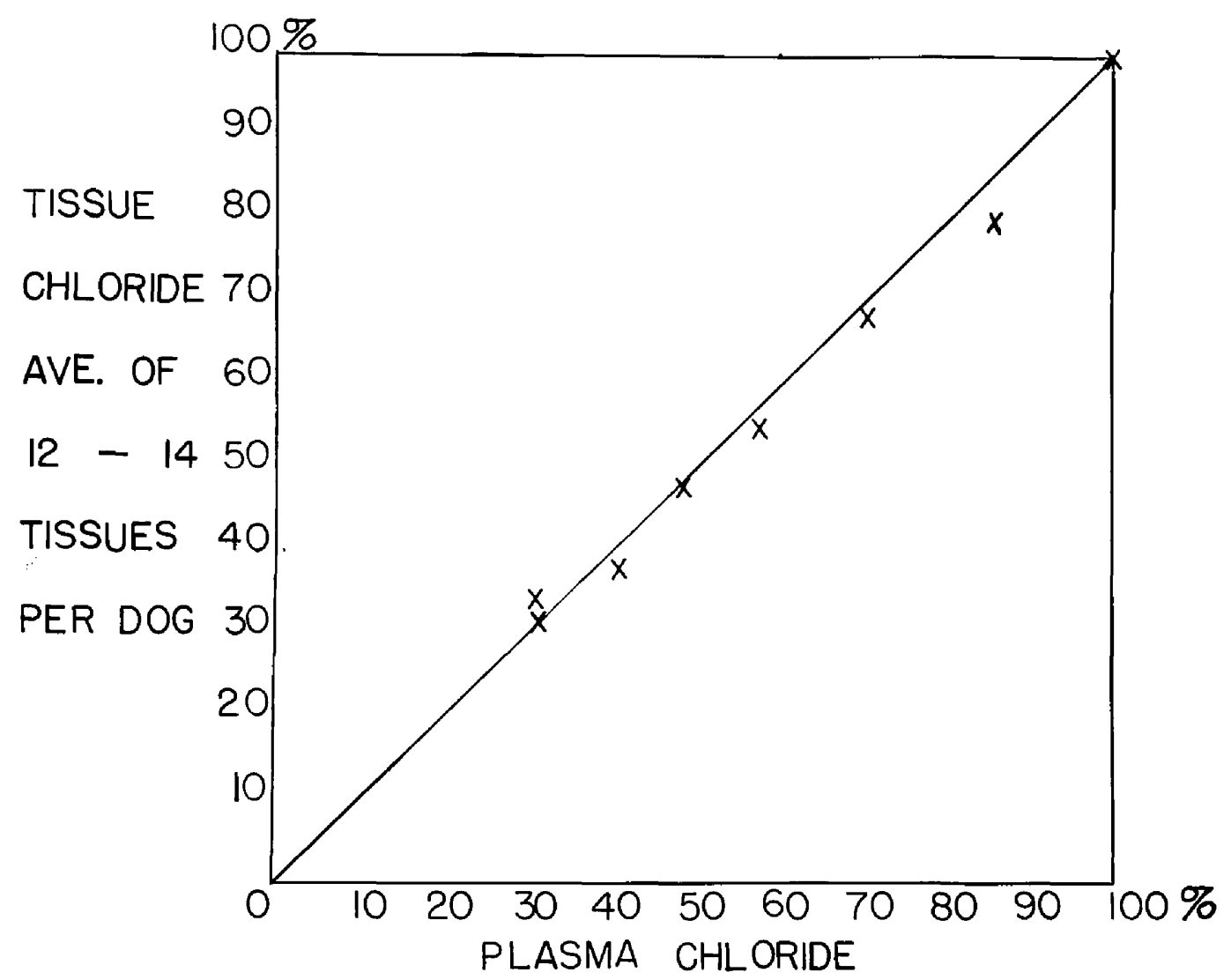

Fig. 1. Average tissue chloride concentration plotted against plasma chloride concentration at various low-chloride levels. Expressed as percentage of average normal value. 


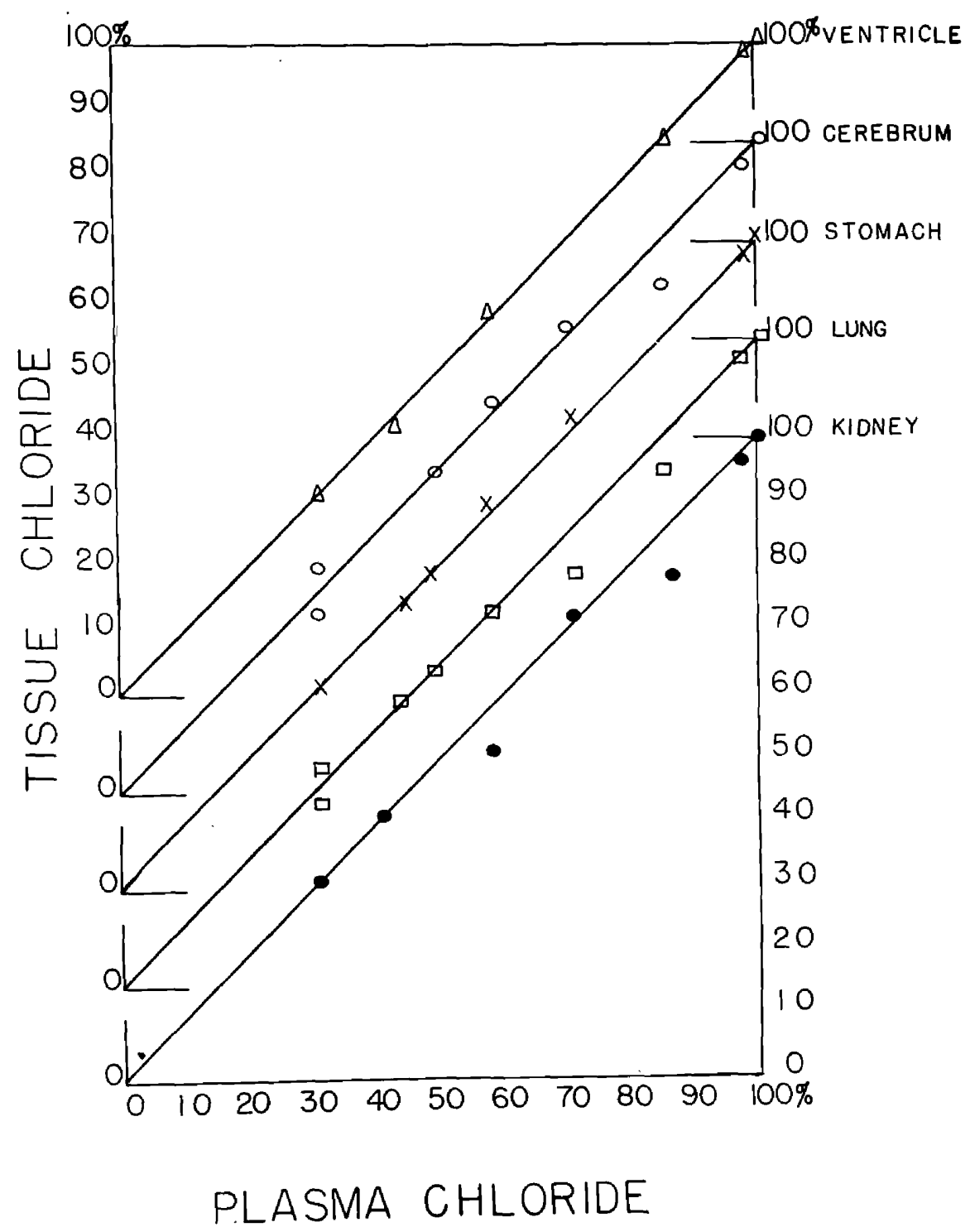

Fie. 2. Individual tissue chloride concentrations plotted against plasma chloride concentration at various low-chloride levels. Expressed as percentage of average normal value. 
2. After Administration of NaCI to Low-Chloride Dogs. Three of the low-chloride dogs were given intravenous injections of enough four times isotonic NaCl solution to raise the plasma chloride to normal level. After periods of fifteen, seventyfive, and one hundred and fifty minutes the animals were killed for chloride analyses. The animals were denied water during the above period.

We found that in these relatively short periods of equilibration the chloride content of the tissues did not rise in direct proportion to the chloride concentration of the plasma. ifost tissues increased more rapidly than the plasma in chloride content, but the brain, the cerebrospinal fluid and the aqueous humor lagged behind the plasma.

In Table II the tissues have been arranged in order according to the percentage of average normal chloride content found in the tissue after a fifteen minute period of equilibration. There is a considerable variation in the different tissues which decreases somewhat with longer periods of equilibration. At the end of one hundred and fifty minutes all the values except those for brain and cerebrospinal fluid are well above the normal levels. Since the dogs were not given the same dose of Nacl per unit of weight, the changes in chloride concentration of any one tissue with time can not be accurately followed. However, we can see some consistent differences in the way the various tissues and body fluids increase in chloride content as follows: (I) Ifuscle tissue shows by far the greatest percentage increase in chloride. It reaches a percentage of normal chloride 
TABLE II

TISSUE CHLORIIES OF LOW-CHLORIDE DOGS INJECTED WITH NaCI

(Expressed as percentages of average normal chloride values.)

TISSUE $D \quad O \quad G \quad S$

\section{\#49 \\ Wt. $5.7 \mathrm{~kg}$. \\ $8 \mathrm{gm} . \mathrm{NaCl}$}

15 min. before death plasma 01 rose from 62.6 to $114.0 \mathrm{meq} / \mathrm{L}$.

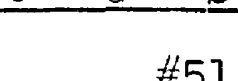

mt. $6.4 \mathrm{~kg} \cdot$

$75 \mathrm{~min}$. before death plasma Cl rose from 62.8 to $110.8 \mathrm{meq} / \mathrm{I}$.

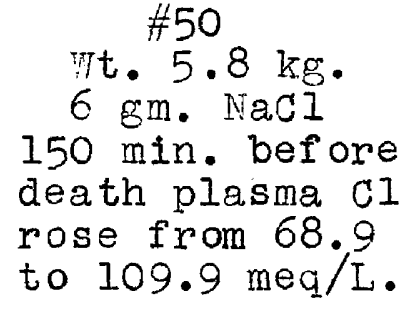

150

t. $5.8 \mathrm{~kg}$.

$6 \mathrm{gm}$. NaCl

$150 \mathrm{~min}$. before death plasma Cl rose from 68.9 to $109.9 \mathrm{meq} / \mathrm{L}$.

\begin{tabular}{llll}
\hline Plasma & $105.5 \%$ & $102.3 \%$ & $101.5 \%$ \\
Ventricle & 215.5 & 128.8 & 141.5 \\
Leg muscle & 194.5 & 130.0 & 180.0 \\
Pancreas & 135.3 & 108.7 & 116.7 \\
Liver & 129.5 & 122.0 &.. \\
Kidney & 120.5 & 116.0 & 121.8 \\
Spleen & 120.5 & 111.0 & 113.7 \\
Stomach & 120.0 &... & 113.7 \\
Duodenum & 108.5 & 111.0 & 120.0 \\
Tendon & 107.8 & 101.9 & 110.0 \\
Lung & 103.0 & 104.0 & 120.5 \\
Skin & 98.5 & 112.0 & 130.3 \\
Aqueous humor & 87.2 &... & 109.7 \\
Cerebrum & 86.7 & 103.5 & 102.0 \\
Cerebrospinal & 86.8 & 92.5 & 92.2 \\
fluid & 86 & &
\end{tabular}


much higher than the other tissues within fifteen minutes, and is still far above other tisgues at the end of one hundred and fifty minutes.

(2) Most of the tissues rise to a percentage of normal chloride higher than plasma within fifteen minutes and remain higher for at least one hundred and fifty minutes.

(3) Cerebrum, cerebrospinal fluid and aqueous humor lag behind the plasma in percentage of normal chloride in the fifteen minute period, and at the end of one hundred and fifty minutes are still below the other tissues.

\section{B. Changes in Blood Chemistry}

The injected nitrate is excreted into the urine, causing intensive diuresis. During this diuresis chloride is also excreted into the urine, even at low levels of plasma chloride concentration. Table III shows some plasma nitrate determinations indicating roughly the rate at which NO3 leaves the blood. There is some indication that nitrate remains in the blood for a longer time at quite low chloride levels, as indicated in Table IV. It is also interesting to note that nitrate penetrates slowly in to the cerebrospinal fluid, as shown in Table $V$.

Table VI shows the changes observed in various constituents of the blood of nine dogs treated with nitrate. As the chloride concentration decreased, the bicarbonate concentration rose, but not enough to make up the osmotic deficit, so that the depression of the freezing point decreased. The $\mathrm{pH}$ was increased by the bicarbonate rise, so that a condition of chronic alkalosis 
TABLE III

RATE OF EXCRETION OF NITRATE

\begin{tabular}{|c|c|c|c|c|}
\hline DOG & PLASMA $\mathrm{NO}_{3}$ & TIME & AFTER INJECTION & REMARKS \\
\hline \multirow[t]{5}{*}{$\# 45$} & 28.90 & & 10 minutes & Plasma Cl $103.4 \mathrm{meq} / \mathrm{L}$. \\
\hline & 10.45 & & 2 hours & $36.1 \% \mathrm{NO}_{3}$ remainine \\
\hline & 9.70 & & 4 hours & $\cdot \cdot \cdot \cdot$ \\
\hline & 5.10 & & 24 hours & $17.6 \% \mathrm{NO}_{3}$ remaining \\
\hline & Trace & & 48 hours & $\cdot \cdot \cdot \cdot$ \\
\hline \multirow[t]{4}{*}{42} & 41.60 & & 10 minutes & Plasma cl $55 \mathrm{meq} / \mathrm{I}$. \\
\hline & 18.50 & & 2 hours & $44.5 \% \mathrm{NO}_{3}$ remaining \\
\hline & $7 \cdot 78$ & & 24 hours & $18.7 \% \mathrm{NO}_{3}$ remaining \\
\hline & Trace & & 48 hours & $\cdot \cdot \cdot \cdot$ \\
\hline \multirow[t]{2}{*}{$\# 41$} & 46.00 & & 3 minutes & Plasma Cl $60 \mathrm{meq} / \mathrm{L}$. \\
\hline & 2.30 & & 24 hours & $5 \% \mathrm{NO}_{3}$ remaining \\
\hline \multirow[t]{2}{*}{$\# 50$} & 33.40 & & 20 minutes & Plasma cl lob.7 meq/L. \\
\hline & 12.10 & & 1 hour & $36.2 \% \mathrm{NO}_{3}$ remaining \\
\hline
\end{tabular}


TAELE IV

RETENTION OF $\mathrm{NO}_{3}$ IN LON-CHLORIDE ANIMALS

\begin{tabular}{|c|c|c|c|}
\hline DOG & $\begin{array}{c}\text { PLASMA } \mathrm{NO}_{3} \\
\text { m.eq. } \mathrm{LI} .\end{array}$ & TIME AFTER INJECTION & REMARKS \\
\hline \multirow[t]{3}{*}{$\# 45$} & 14.20 & 18 hours & Plasma Cl $35 \mathrm{meq} / \mathrm{L}$. \\
\hline & 16.50 & 42 hours & $\begin{array}{l}\text { Hematocrit indicates } \\
\text { decreased blood vol. }\end{array}$ \\
\hline & 8.80 & 66 hours & . . . . \\
\hline \multirow[t]{2}{*}{$\# 40$} & 14.00 & 24 hours & Plasma CI $52 \mathrm{meq} / \mathrm{L}$. \\
\hline & 8.15 & 6 days & $\cdot \cdot \cdot \cdot$ \\
\hline \multirow[t]{2}{*}{$\# 42$} & $7 \cdot 78$ & 24 hours & Plasma Cl 54 meq/L. \\
\hline & 5.74 & 72 hours & Plasma $C \perp 54$ meq/L. \\
\hline
\end{tabular}

\section{TABLE V}

PENETRATION OF $\mathrm{NO}_{3}$ INTO CEREBROSPINAL FLUID

\begin{tabular}{|c|c|c|c|c|}
\hline DOG & $\begin{array}{l}\text { Cl LEVEL } \\
\text { m.eq/L. }\end{array}$ & $\begin{array}{c}\mathrm{NO}_{3} \text { IN PLASMA } \\
\text { m. eq./L. }\end{array}$ & $\begin{array}{c}\mathrm{NO}_{3} \text { IN OIREBRO- } \\
\text { SPINAL FIUID } \\
\text { m.eq./L. }\end{array}$ & REIARKS \\
\hline$\# 45$ & 35.0 & 15.75 & 19.40 & 3 wiks. of $\mathrm{NO}_{3}$ inj. \\
\hline$\# 48$ & 46.0 & 3.40 & 2.03 & 2 wks. of $\mathrm{NO}_{3}$ inj. \\
\hline$\# 50$ & 105.7 & 12.10 & 3.10 & I hr. after lst inj \\
\hline$\# 51$ & 97.5 & 33.65 & 5.00 & $5 \mathrm{hr}$. after lst ing. \\
\hline
\end{tabular}


BLOOD CHEMTSTRY OF NORMAI AND LOW-CHLORIDE DOGS

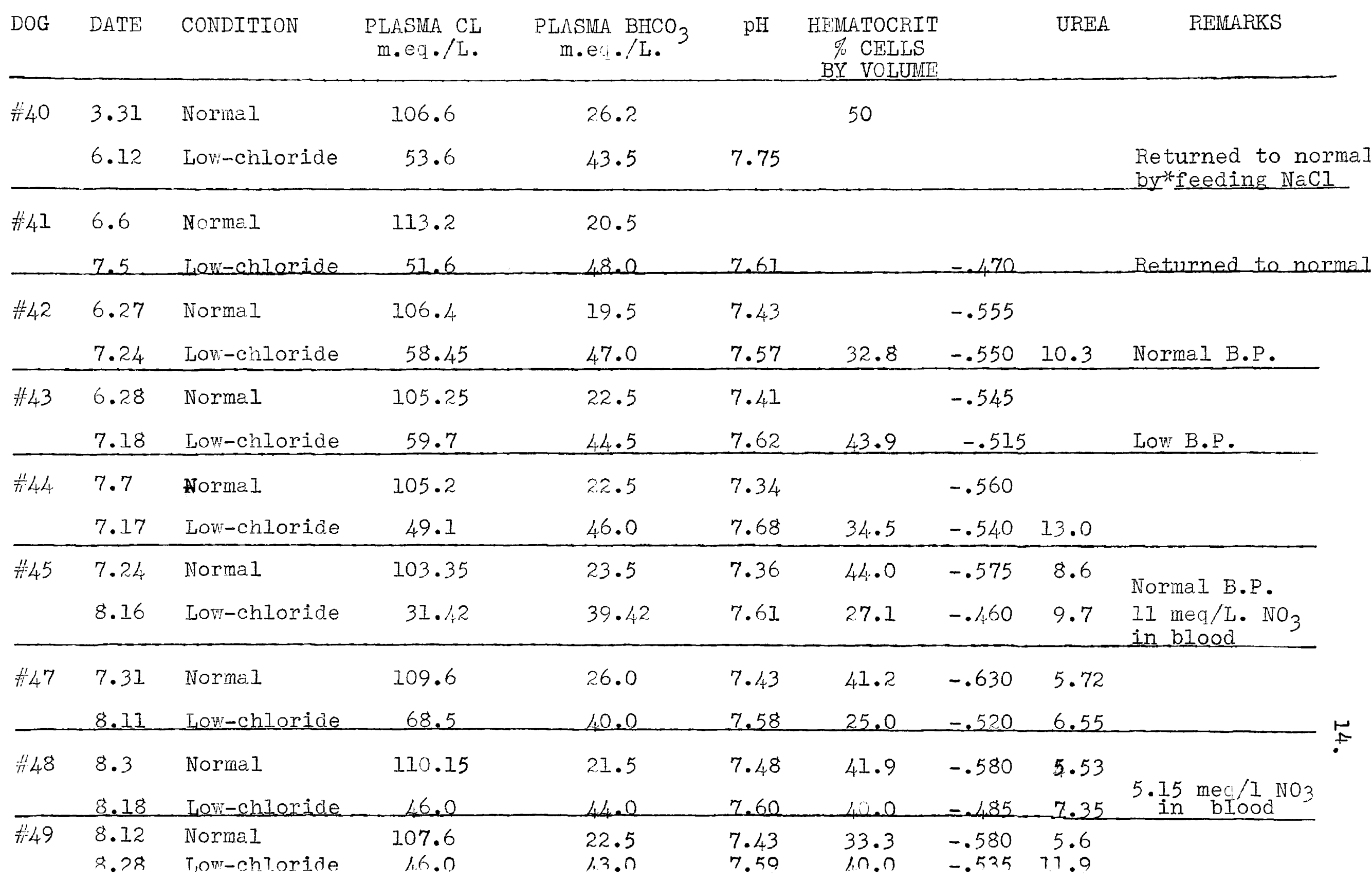


resulted. However, the pH seldom rose above 7.65 even when the bicarbonate was over twice the normal concentration. The urea concentration in the plasma usually rose only slightly, although in one case definite uremia was observed. The lactic acid remained approximately constant. The hematocrit usually, but not invariably, decreased. Most of the dogs showed a marked increase in the rate of sedimentation of erythrocytes in their blood. Fig. 3, drawn to fit $\operatorname{dog} \# 48$, shows changes in the blood constituents which are typical of those seen in low-chloride dogs.

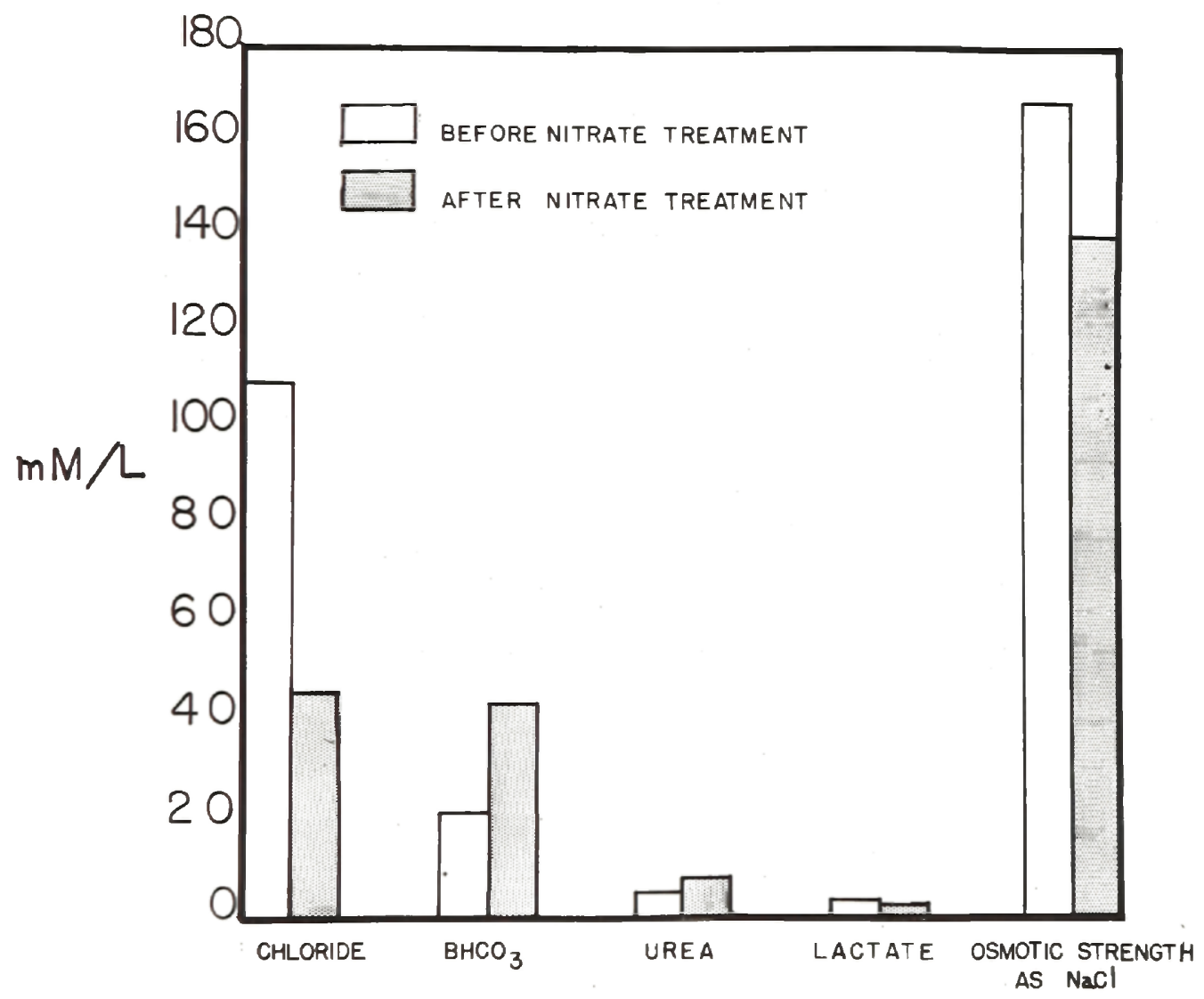

Fig. 3. Typical changes in blood constituents of low-chloriae dogs. 
The osmotic pressure did not decrease in proportion to the total of the osmotic constituents analyzed. This points to an increase in some other blood substance or substances. After administration of $\mathrm{NaCl}$ the entire blood picture again became normal, except for a continuing low hematocrit reading.

c. General Physiological Changes During Hypochloremia

We can verify the observation of Ambard et al (1935) that dogs can lose up to $40 \%$ of their chloride without obvious ill effects. They seemed to be quite normal, ate well, and maintained their weight. However, as their chloride content was Lowered still more, symptoms of physiological imbalance appeared. The level at which these symptoms appeared was quite variable in different dogs. The nose and mouth became dry, and thick secretions accumulated around the eyes. The animals failed to keep themselves clean, perhaps because of a lack of saliva. Their appetites decreased finally to the extent of complete failure to eat. At the same time there was a decrease in the amount, total acidity and chloride of the gastric juice withdrawn by stomach tube an hour after the subcutaneous injection of $0.5 \mathrm{mg}$. of histamine. The lact that the appetite of these dogs suacien $\perp$ y returns when they are given enough NaCl to restore a normal chloride concentration in the plasma indicates that the anorexia was not due to distasteful food.

If we continued to remove chloride from the dogs, they eventually were completely prostrated, as though they had rather 
suddenly reached the limit of their adaptability. This collapse occurred at variable chloride levels below 40 of normal. We endeavored to stop short of this state in most of our experiments.

Nitrate entered the gastric juice produced after injection of histamine rather slowly even when there was a considerable concentration of nitrate in the plasma. We were not able to ascertain positively whether any of this nitrate was secreted as $\mathrm{HNO}_{3}$.

In three of the low-chloride dogs we measured blood pressure by carotid cannulation. Two of the se had normal systolic blood pressures of from 110 to $125 \mathrm{~mm}$. Hg. The third dog had a low blood pressure of around $80 \mathrm{~mm}$. Hg. In our other dogs it was apparent from the color and rate of flow of venous blood when samples were taken that some of them were maintaining their blood pressure while others were not.

After the plasma bicarbonate had increased to around $40 \mathrm{~m} . e \mathrm{q} . / \mathrm{L}$. the dogs ceased to pant. At the same time their activity was observed to be definitely decreased. They appeared to be in a delicate balance between a rise in body temperature and over-ventilation-alkalosis.

Two of our low-chloride dogs were supplied with an extra water pan containing $1 \% \mathrm{NaCl}$ solution. In spite of efforts to coax them to take some of the salt solution, they drank only plain water. Rpparently these dogs do not have the salt hunger characteristic of animals on a low-sodium diet. 


\section{DISC USS ION}

It is especially interesting to compare the ratio of plasma chloride to tissue chloride of these low-chloride dogs With the ratios obtained by Amberson, Nash et al (1938). They removed chloride from cats by plasmapheresis with a chloridefree artificial blood made of beef red cells, gum acacia and an isotonic salt solution made up with sulfates. In acute experiments it was found that the chloride of some tissues, viz. stomach, spleen, salivary gland, and central nervous tissue, did not vary directly with plasma chloride, but instead retained a higher percentage of their chloride than the plasma. Indeed they found that the central nervous tissues retained almost all of their chloride. They suggest that this may be evidence for an indiffusible fraction of chloride, perhaps intracellular. In our use of nitrate we have seen no such retention, except in the cerebrospinal fluid, in animals which were allowed ample time to reach electrolyte equilibrium. It remains to be seen whether this difference in our results is due to a more complete equilibrium attained by our animals or whether the nitrate is actually able to supplant chloride in some fluid volume or chemical combination which sulfate is unable to enter. The slow resaturation of brain and cerebrospinal fluid with chloride indicates that even chloride encounters more resistance in entering central nervous tissues and fluids than in entering other tissues.

The partial independence of the cerebrospinal filuid of fluctuations in the chloride content of the plasma has been 
encountered by several investigators (see Katzenelbogen, 1935). It would seem that in ordinary conditions the exchange between blood and cerebrospinal fluid is quite sluggish, although it is well known that this fluid is produced in copious amounts when there is drainage to the exterior.

The results on the resaturation of tissues with injected NaCl can be accounted for by an hypothesis which agrees with the evidence presented by Hanery and Hastings (1939) indicating that there are three chemically different phases or volumes in tissues:

(1) An extracellular phase in ionic (Donnan) equilibrium with blood plasma and consisting essentially of plasma ultrafiltrate and connective tissue proteins.

(2) An intracellular phase which contains neither sodium nor chloride and is exemplified by muscle fibers.

(3) An intracellular phase which contains chloride and may or may not have sodium in equivalent proportions, e.g. blood cells and connective tissue cells.

The relative proportions of these phases is quite variable in different tissues. Manery and Hastings base this classification on calculations made from determinations of chloride, sodium and potassium in various tissues.

If a tissue consisted principally of phases (1) and (2) it would rapidly increase in chloride content after administration of Nacl. Moreover, the chloride content would rapidly rise to a level considerably above the normal value because the extra $\mathrm{NaCl}$ on entering the extracellular phase (I) would make that phase hypertonic to the intracellular phase (2). This would cause water to pass from phase (2) to phase (1), thus increasing 
the volume of the latter at the expense of the former. Hence in a sample of this tissue there would now be relatively more of phase (1) than in a normal tissue. Since phase (1) contains the chloride, the tissue would then have more chloride per unit of volume than would a normal tissue. This explanation would account for the high percentages found in muscle, which is known to be principally made up of phases (1) and (2) (see Fenn, 1936).

However, if there were proportionately less of the chloride-impermeable phase in a tissue, there would be less percentage rise in chloride content. For the increase in tissue chloride would be proportional to the amount of water which shifts from the intracellular phase (2) to the extracellular phase (I). We assume that chloride enters phase (3) so rapidiy that there is little loss of water from the cells of this phase. The fact that the skin, tendon and lung appear to be in direct proportion to the plasma in their chloride content at the fifteen minute period is evidence in favor of the above assumption. These tissues are known to contain a large proportion of connective tissue and a small proportion of chloride-impermeable volume. According to our figures the duodenum would also belong in this class. However, by the end of one hundred and fifty minutes these four tissues have risen above direct proportionality with the plasma. This might be due to a general distribution of excess extracellular fluid from other tissues. In short, by this time we have a Eeceralized edema which is stilI most pronounced in striated muscle tissue. Ey the above reason- 
ing the tissues in Table II could be said to be arranged in order according to the proportionate amount of chloride-impermeable phase ( 2 ) in the tissue, with those containing the most of phase (2) at the top of the list.

However, the behavior of the cerebrum in this series of experiments would indicate that it belongs in a class by itself. To account for the lag it shows in resaturation with chloride we have considered two hypotheses.

First, that there is a barrier to electrolytes between the vascular supply to the brain and the rest of the tissue. This hypothesis has been advanced by Wallace and Brodie (1938) and by weir and Hastings (1939) to account for the fact that bromide does not penetrate brain tissue and cerebrospinal fluid to the same extent that it does other tissues. rallace and Brodie have found that iodates and thiocyanates behave in the same manner. Since they find that bromide, iodide and thiocyanate penetrate the brain to the same degree as they penetrate cerebrospinal fluid, they suggest that cerebrospinal fluid is an intermediary between blood and brain and is in ready equilibrium with the extracellular fluid of the brain. Second, that some of the chloride of the brain is less diffusible than is the chloride of other tissues. This has been suggested by Amterson et al to account for the failure of sulfate to replace chloride in central nervous tissues in their plasmapheresis experiments. Chloride would be less diffusible if it entered into a slowly dissociating compound or if it entered cells with membranes which would not permit a rapid movement of 
chloride into or out of the cells. This hypothesis has also been suggested by Oster and Amberson (in press) to account for the fact that brain chloride resists electrodialysis more than does the chloride of other tissues.

The main discrepancy we find when we try to fit the first hypothesis to our results is that in our experiments the cerebrum and the cerebrospinal fluid varied independantly. The cerebrum always came gradually into direct equilibrium with the plasma, but the cerebrospinal fluid lagged behind, whether we were decreasing or increasing the concentration of chloride. when we try to apply the second hypothesis to our data we are again in difficulty. Manery and Hastings (1939) have found that the proportion of sodium to chloride in the brain is the same as in an ultrafiltrate of blood plasma. This is evidence that chloride is not entering into any combination except with sodium, and it also means that if chloride is penetrating the cells it is accompanied by sodium. If we assign some of the sodium and chloride to the cells, then we must decrease any estimates of extracellular water based on the concentration of these ions in it. If we assumed this to be true, we could account for our results and for the comparatively low ratio of bromide to chloride found in the brain by wallace and Brodie. Such an assumption would mean that the barrier of Nallace and Brodie was the cell membrane. But this would not explain the fact that these investigators found that the brain and the cerebrospinal fluid admitted bromide, iodide and thiocyanate to almost exactly the same degree, as measured by the concentra- 
tion.

We have not been able successfully to apply either hypothesis to all the data. Until we have more crucial evidence we are unable to account for the behavior of the brain in regard to electrolyte equilibria with the blood.

As for the aqueous humor and the cerebrospinal fluid, there is already a well-supported theory that these fluids are not in ready osmotic equilibrium with the blood and only slowly respond to changes in the composition of the blood. For a discussion of the relationship between plasma and aqueous humor see Robertson (1939), and for cerebrospinal fluid see Katzenelbogen (1935).

The blood changes in our dogs differed in some respects from those reported in animals brought to a low chloride level by other means. The most widely discussed low chloride condition is that which results from a continued loss of gastric juice. This may result from the chronic vomiting of high intestinal obstruction and pregnancy toxemias; from fistulas, pathological or experimental; or from the experimental removal of the juice (see Dragstedt and Ellis, 1930; Peters and Van Slyke, 1931; and Bottin, 1936). Loss of gastric juice results in a decrease of both plasma base and chloride, but the loss of the latter is greater. This is because there is always an increase in plasma bicarbonate, usually accompanied by alkalosis, although Bottin reports a slight acidosis. There is usually dehydration bringing about a low blood pressure, which in turn causes renal insufficiency with a consequent rise in plasma N.P.N., urea, phosphate and sulfate. 
Most of our dogs did not show extreme dehydration, if normal blood pressure, maintenance of weight and normal renal function can be taken as evidencefor normal fluid volume. In this respect they are like the dogs of Ambard et al (1935). The latter injected histamine and then apomorphine to cause vomiting. By repeating this treatment a number of times they were able to remove as much as $40 \%$ of the chloride from their dogs. They report that the dogs maintained normal appetite, renal function and nutrition when in this condition.

An increase in the rate of sedimentation has also been reported (Haden and Orr, 1926). The decrease in the hematocrit readings probably indicates that there was destruction of erythrocytes. This might be due to a slight but continuous formation of methemoglobin by the action of nitrites as long as there is nitrate in the blood. It does not seem likely that the decrease in cell volume could have been due to a dilution of the blood.

A decrease in the osmotic pressure of the blood has been observed by nccance (1937) in men who lost large quantities of electrolyte in sweat. He reports also (1936) that they lost their sense of taste. This might be a contributing factor to the anorexia of our dogs. However, his findings differed from ours in that he found (1) no increase in bicarbonate, (2) a definite dehydration and (3) a craving for salt. Darrow and Yannet (1935) have observed a dehydration and decrease in osmotic pressure in dogs from which they removed electrolyte by 
intraperitoneal lavage. In both of these cases the reduction in total chloride content was slight compared to that which we were able to obtain.

It has been said that the kidneys regulate first the composition of the body fluids and only secondarily the total volume of these fluids (Peters, 1935). As our dogs were reduced to a low-chloride state it seemed that they wavered between these two objectives. There was usually an initial attempt to maintain the composition of the body fluids by dehydration, but most of the dogs seemed to abandon this effort in favor of maintaining a normal volume of fluid by decreasing the osmotic pressure.

Our observation that the gastric secretion of these dogs was decreased in their low-chloride condition is not in agreement with a number of investigators who have found that continuous removal of gastric juice from animals did not radically alter the composition of the gastric fluid (Dragstedt and Ellis, 1930; Lim and $\mathrm{Ni}, 1925-26$; and $\mathrm{He}$ ILinghof $f$ and Heuschert, 1934). Perhaps this is because our dogs were at a lower chloride level.

The indispensability of the chloride ion in the regulation of osmotic pressure and acid-base balance has been remarked Iong ago by Gamble and Ross (1924-25), who tried in vain to relieve the dehydration of intestinal obstruction by injecting salts with various other anions ( $\mathfrak{y B r}_{3}, \mathrm{Na}_{2} \mathrm{SO}_{4}, \mathrm{ireSO}$, $\left.\mathrm{NaH}_{2} \mathrm{PO}_{4}, \mathrm{Na}_{2} \mathrm{HPO}_{4}\right)$. However, they found that the chloride salts ot potasium, calcium, magnesium and ammonia were not any better. Both sodium and chloride are necessary to relieve the 
dehydration. In our dogs the kidney, after having been exposed to a very different blood for weeks or months, was able to restore the normal composition of the blood as soon as $\mathrm{NaCl}$ was provided. These low-chloride animals can live indefinitely in the low-chloride condition in a fair state of health. Such animals should be or value as experimental material in the further study of problems in the physiology of electrolytes. 


\section{SUMMARY}

1. Dogs were caused to lose as much as $70 \%$ of their total body chloride by the intravenous administration of large doses of sodium nitrate over a period ( $1-13$ weeks) during which the animals were fed on a low-chloride diet.

2. In such dogs all of the fourteen tissues examined and the aqueous humor varied directly with the plasma in chloride content when a long period was allowed for equilibrium. The cerebrospinal fluid retained a higher percentage of its chloride.

3. Then a large quantity of sodium chloride was rapidly injected into the blood of these dogs, the rate at which the chloride content of the various tissues and fluids rose diftered markedly. The brain and cerebrospinal fluid especially lagged behind. Possible explanations are discussed.

4. The injected nitrate was rather promptly excreted, except at very low chloride concentrations, when it was excreted much more slowly.

5. In the blood of these low-chloride aninals the re was an increase in bicarbonate and $\mathrm{pH}$, and a decrease in osmotic strength. Urea concentration usually increased, but nor markedly. Lactic acid concentration varied little from normal. The volume of cells in the blood usually decreased. The rate of sedimentation was very rapid in some of these dogs.

6. At chloride levels below $65 \%$ of normal the dogs may show dryness of eyes, nose and mouth. They develop anorexia (correlated 
with a decrease in the volume and total acidity of the gastric secretion), and cease to pant after the bicarbonate has climbed to akout 40 milliequivalents per liter.

7. These low-chloride dogs refused to drink $1 \% \mathrm{NaCl}$ solution, indicating that they do not suffer from the salt hunger characteristic of animals on a sodium poor diet. 


\section{ACKNOWLEDGEMENTS}

I wish to express deep appreciation to Dr. William $R$. Amberson for his valuable advice and criticism, as well as for the technical facilities which he placed at my disposal.

I also wish to recognize the able technical assistance of Emily J. Kemp, Joye E. Jacobs, Walter B. Rowe, Jewett Goldsmith and Dorothy Hiatt. 
LIIERATURE CITED

1. Ambard, I., J. Stahl and D. Kuhlman: Ann. de rifed. 38:46, 1935

2. Amberson, W. R., T. P. Nash, A. Mulder and D. Binns: Am. J. Physiol. 122:224, 1938

3. Austin, J. H. and L. Jonas: J. Biol. Chem. 33:91, 1918

4. Bottin, J.: Rev. Belge des Sc. Med. 8:97, 1936

5. Chamot, I. M., D. S. Pratt and H. W. Redfield: Jour. Am.

Chem. Soc. 33:366, 1911

6. Darrow, D. C. and H. Yannet: Jour. Clin. Invest. 14:266, 1935

7. Dragstedt, L. R. and J. C. Ellis: Am. J. Physiol. 93:407, 1930

8. Eisenman, A. J.: Jour. Biol. Chem. 82:411, 1929

9. Fenn, W. O.: Physiol. Rev. 16:450, 1936

10. Fulton, M. N., H. A. Van Auken, R. J. Parsons and L. F. Davenport: J. Pharm. \& Exp. Therap. 50:223, 1934

11. Gamble, J. L. and S. G. Ross: Jour. Clin. Invest. 1:403, 1924

12. Grutnmald, H. F.: Arch. f. Exp. Pathol. 60:360, 1909

13. Haden, R. L. and T. G. Orr: Jour. Exp. Med. 44:419, 1926

14. Katzenelbogen, S.: "The Cerebrospinal. Fluid and 1ts Relation to the Blood". Johns Hopkins Press, Baltimore, 1935

15. Keith, N., M. The lan and F. Eannick: Arch. Int. Med. $46: 797,1930$

16. Langlois, J. P. and C. Richet: Jour. de Physiol. et Path. $2: 742,1900$

17. Lim, R. K. .. wind J. G. Mj.: Am. J. Physiol. 75:475, 1925-26

18. Ircjance, R. A.: Proc. Roy. Soc. Lon., Series B 119:245, 1936 
19. Wic Cance, R. A.: Biochem. J. 31:1278, 1937

20. Manery, J., I. S. Danielson and A. B. Hastines: Jour. Biol. Chem. 124:359, 1938

21. Vanery, J. and A. B. Hastings: Jour. Biol. Chem. $127: 657,1939$

22. Mellinghoff, K. and C. A. Heuschert: Klin. Nschr. $10: 1247,1954$

23. Moss, K. N.: Proc. Roy. Soc. Lon., Series B 95:181, 1923

24. Oster, R. H. and N. R. Amberson: Jour. Biol. Chem. (in press)

25. Padtberg, J.H.: Arch. f. exper. Path. u. Pharmakol. $63: 60,1910$

26. Eeters, J. P.: "Body Water", Chas. C. Thomas, Baltimore, 1935

27. Peters, J. P. and D. D. Van Slyke: "Quantitative Clinical

Chemistry, Vol. I, Interpretations", Wms. \& "ilkins,

Baltimore, 1931

28. Peters, J. P. and D. D. Van Slyke: "Quantitative Glinical

Chemistry, Vol. II, Hethods", Wms. \& Milking, Daltimore, 1932

29. Robertson, J. D.: Brit. Jour. Ophthal. 23:170, 1939

30. Skelton, H.: Arch. Int. Med. 40:140, 1927

31. Tarr, L.: Arch. Inter. Med. 51:38, 1933

32. Van Slyke, D. D. and J. Sendroy: Jour. Biol. Chem. $78: 765,1928$

33. Nallace, G. B. and B. B. Brodie: Jour. Pharm. \& Exp. Therap. 65:220, 1939

34. "eir, E. G. and A. B. Hastings: Jour. Biol. Them. 129:547, 1939

35. West, E. S.: Jour. Biol. Chem. 92:483, 1931 
ABSTRAC T 